\title{
Information Technology Capabilities: Suggestions for SME Growth
}

\author{
Donald L. Lester \\ Middle Tennessee State University \\ Thuhang T. Tran \\ Middle Tennessee State University
}

\begin{abstract}
The manner in which small-to-medium-sized (SMEs) organizations grow and develop has been a focused interest of management researchers for decades. Categorizing this development into a life cycle of organizations has been a goal of researchers for understanding the problems and opportunities associated with growth. Using Kazanjian's four-stage organizational life cycle model (1988) to represent the crises or critical problems faced in each stage, this paper explores how information technology (IT) capabilities can address the critical problems of each life cycle stage (i.e., conception and development, commercialization, growth, and stability) to facilitate continued growth and development.
\end{abstract}

\section{Introduction}

The concept of organizational development has been an important research agenda for decades. The issue is why some entities grow and even flourish while others muddle along, falter then surge, or completely go out of existence. Categorizing organizational development into a life cycle of organizations has become a commonly accepted method for understanding the problems and opportunities associated with growth. Essential to this life cycle construct is the identification of critical problems to overcome during each stage if an organization is to continue to grow, rather than stagnate or regress.

Such a life cycle model that not only describes discrete stages of development but also identifies the critical problem to overcome during each stage has been put forth by Kanzanjian (1988) which is particularly important because of its emphasis on early development issues involving small to medium sized enterprises (SMEs). A key component of SME operation in today's competitive environments is information technology (IT). We propose that IT can ameliorate the crises of growth at each stage of Kanzanjian's organizational life cycle, enabling small businesses to grow and flourish. Recent surveys of small business owners/managers revealed that $66 \%$ are using the Internet in their business, $77 \%$ feel that a web site is a necessity, $60 \%$ wished they had built a web site sooner, and $85 \%$ would recommend other small businesses use this technology (Greenspan, 2002). Furthermore, the wide reach of the Internet and 
other ITs can help SMEs overcome their size disadvantage and internationalize new ventures more quickly (Oviatt \& McDougall, 1995).

A literature review is presented that briefly explores the organizational life cycle construct and a discussion of information technology investment in SMEs. Next a set of propositions is developed pertaining to the relationship between stages of organizational development and information technology capability building. A new model is discussed concerning this relationship and future research is proposed.

\section{Review of the Literature}

\section{Life Cycle Models}

Researchers have tried for decades to categorize organizational growth and development into stages or distinct periods commonly referred to as cycles (Adizes, 1979). Most of this research is based on the biological life cycle construct, identifying a pattern of development from birth to death. The observable evidence that organizations are at some point born, attempt to grow larger and more stable, and eventually die (Kimberly \& Miles, 1980) makes the life cycle model intuitively appealing.

However, empirical research results have varied. Some researchers have found ample support for the renewal of dying or failing organizations through the exercise of strategic choice (Child, 1972; Lamberg \& Pajunen, 2005; Rasheed, 2005), a notion that contradicts the deterministic assumption of the life cycle model (Drazin \& Kazanjian, 1990; Lester, Parnell, \& Carraher, 2003; Lohdal \& Mitchell, 1980). Churchill \& Lewis (1983) note that some firms reach a situation that tends to stay relatively the same for long periods of time, never growing beyond, for example, the first or second stage of the life cycle. Others have documented organizations that progress to a mature stage only to fall back to a growth stage (Miller \& Friesen, 1984), demonstrating that it is not inevitable that organizations must follow a natural progression from birth to growth to maturity to decline. Furthermore, SMEs do not all progress through the life cycle stages at the same rate, with some operating at low growth rates in a traditional SME model, others at a moderate pace in a capped growth model, and a third group at a high growth rate in an entrepreneurial model of SME (McMahon, 2001).

While a life cycle stage is a loosely comprised set of organizational activities and structures (Dodge, Fullerton, \& Robbins, 1994; Hanks, et al., 1994; Quinn \& Cameron, 1983), it can be determined using four gestalts: strategy, structure, decision making style, and situation (Miller and Friesen, 1984). Almost all life cycle models of organizations have multiple stages which vary in length from ten (Adizes, 1979) to three stages (Smith, Mitchell, \& Summer, 1985; Galbraith, 1982). A thorough synthesis presented by Hanks (1990) concluded that most 
researchers of the life cycle construct generally agree on five distinct stages: start-up, expansion, consolidation, diversification, and decline.

Most attempts at organizational life cycle present a metamorphosis model, a snapshot of problems encountered by organizations at different stages of growth and how they cope with those problems (Starbuck, 1971). Few models have explicitly detailed how an organization actually moves forward or transitions to a new stage (Kazanjian, 1988), creating a gap in the literature that can only be filled with empirical life cycle research. One exception is the detailing of the complete life cycle of a small family business by Lester \& Parnell (2006).

A key contribution from the life cycle models for researchers and practitioners alike is an understanding of how an organization's activities and structures change over time. For example, firms shift their focus to different stakeholder groups as they evolve from one stage to the next because of the change in contribution provided and attention required from each stakeholder (Jawahar \& McLaughlin, 2001). Social capital, external networking and coaching needs are more intense and hands-on during the early stages for innovative start-ups (Clarysse \& Bruneel, 2007; Maurer \& Ebers, 2006). In the first three stages of the life cycle, diversification in sales, differentiation in labor force, and level of labor productivity increases relative to the last stage (Masurel \& van Montfort, 2006).

What has emerged from the literature, both theoretical and empirical, is the notion of a crisis that occurs at some point of organizational growth that must be overcome if progress is to continue. Some organizations grow in an evolutionary manner, with occasional periods of revolution that lead to the need for leadership, coordination, and control (Greiner, 1972). According to Smith et al. (1985), major priorities for managers include technical efficiency, organizational coordination, and political support. More specifically, the crises identified are leadership at the entrepreneurial stage, delegation at the collectivity stage, flexibility development in the bureaucracy at the formalization stage, and need for revitalization in the elaboration stage (Quinn \& Cameron, 1983). These crises must be solved during each stage or firms will stagnate and/or die.

\section{$\underline{\text { Information Technology Capabilities }}$}

Another stream of literature relevant to this discussion is the ever-increasing importance of information technology (IT) to organizational survival and success. From word processing, to networking, to the internet, to e-commerce, IT has become the driving force in today's global economy. Investment in IT is loosely defined as including computers and telecommunications equipment and their necessary hardware, software, and services (Dedrick, Gurbaxani, \& Kraemer, 2003). Firms regularly invest in IT for such activities as payroll, human resources, accounting, supply chain management, and a host of other functions (Rao, Metts, \& Monge, 2003). While smaller firms have been more reluctant to 
invest heavily in IT, larger firms have found it almost imperative and profitable (Stimmel, 2001). Of particular concern to smaller firms is the resource requirements associated with IT investment (Pool, et al., 2006).

The degree of sophistication of both information and planning and control systems is a prominent factor in determining the success or failure of business growth which becomes increasingly important as businesses grow larger and more complicated (Churchill \& Lewis, 1983). Of course this is not to diminish the importance of the business founder's willingness to delegate responsibility and become a manager of others in the small business growth process. In addition, these systems, such as information systems, must be acquired in advance of growth so that they are in place when needed. By using IT to automate business processes and to improve information gathering, access, and quality, small firms can transform their entire business (Dedrick, et al., 2003). Furthermore, as the phenomenon of multifactor productivity (MFP) maintains, these improvements can be gained without additional investment in resources. Over time, IT investment has been shown to be associated with a shift to higher skilled workers. In fact, Lester, et al. (2003) found information processing to be the strongest indicator of a firm's life cycle stage.

The literature on IT investments by organizations have focused mainly on the antecedents of IT investment, that is, identifying the external, technological, and organizational factors that would persuade a firm to adopt IT. External forces include pressure from competitors, suppliers, and customers as well as the availability of government incentives and technology consultants (Aguila-Obra \& Padilla-Melendez, 2006; Kim \& Jee, 2007). Studies focusing on technological factors have examined the potential benefits and trade-offs of IT investments along with the influence of existing related technologies. Organizational support for IT investment can depend on the firm's structure, processes, size, culture and technological capabilities of various firm members, to name a few.

For SMEs, four factors found to have a profound influence on IT investments are: the perceived cost savings and income generation benefits; external pressure from rivals, suppliers, and buyers; organizational readiness; and perceived ease of use (Grandon \& Pearson, 2004; Mehrtens, Cragg, \& Mills, 2001). IT investment in SMEs differs from IT investment in large firms because a smaller number of people have decision-making responsibility, standard procedures are not instituted, long-term planning is limited, and there is more reliance on external IT experts in SMEs (Premkumar, 2003). Nonetheless, IT capabilities may enable the long term survival of SMEs in a number of ways. They provide access to external knowledge and financial resources, create trust and legitimacy through widespread information dissemination, and generate more social network ties (Morse, Fowler, \& Lawrence, 2007).

IT investment itself is a process that can occur in stages identified as: initiation, adoption, adaptation, acceptance, routinization, and infusion (Aguila-Obra \& 
Padilla-Melendez, 2006). An in-depth qualitative study by Bruque \& Moyano (2007) found that the factors influencing IT investment (e.g., managerial support, firm growth, and firm size) have little or no role in its implementation. Other issues such as staff training, staff socialization, power structure, and hierarchies play a larger role in IT implementation. For SME executives, once an IT is adopted, other challenges remain including keeping current with changing IT, training and educating employees, and receiving timely and accurate information (Riemenschneider \& Mykytyn, 2000).

Our research builds on these two literature streams by using the life cycle approach to create a model of IT capability building that is dynamic. One contribution of this research is that it recognizes that not all IT capabilities are equal or interchangeable in addressing SME growth needs. As a result, a closer more detailed examination of specific IT capabilities and their applications to overcome developmental crises at certain stages of organizational growth is required. In addition, we propose that managers view IT not as a functional tool but as a strategic capability that can provide the SME with competitive advantage.

\section{Kazanjian's Organizational Life Cycle and Crises Model}

Although numerous life cycle models exist, this research uses the four-stage life cycle model developed by Kazanjian (1988) because it primarily focuses on issues important to smaller enterprises that can be addressed through the strategic application of IT capabilities. In addition, Kajanjian's (1988) model is based on empirical organizational life cycle research, as opposed to other SMEbased life cycle models (e.g., Churchill and Lewis, 1983) which are theoretical.

Since its conception, the life cycle model developed by Kazanjian (1988) has been applied in a variety of industry, country, and management application research contexts. For instance, changes in board composition can be understood from the life cycle approach in conjunction with the relative power of CEOs and external financiers (Lynall, Golden, \& Hillman, 2003). A study of biotechnology firms in five countries show that their success is dependent on their ability to harmonize scientific and business plans as these plans develop through the life cycle stages (Ireland \& Hine, 2007). Vohora, Wright, \& Lockett (2004) use life cycles to identify the evolving resource and capability acquisition activities of university spinout companies. Rutherford, Buller, \& McMullen (2003) delve deeper into the human resources management issues Kazanjian identified by examining the specific HR problems of hiring, retention, and training that SMEs face in each stage of the life cycle.

This research seeks to contribute to the life cycle and IT adoption literature as well as build on Kazanjian's four-stage model by addressing how the critical issues identified in this model can be addressed through the strategic development and application of IT capabilities. The following provides a brief 
review of Kazanjian's four-stage organizational life cycle model and the related dominant problems that emerged from a phenomenological study of two hightechnology ventures referred to as alpha and beta and an empirical questionnaire study of 105 ongoing high-technology ventures.

Kazanjian (1988) predicted that stage one is the conception and development stage where something is being invented or some process developed for a business. Constructing and testing a prototype is paramount to continued existence. The need for resource acquisition and technology development become the overwhelming focus during this time. Organizational issues of much importance later, such as structure and formality, are not present during this stage.

Stage two involves commercialization of the process or invention, focusing on production issues related to start-up. Financing, at least initial financing, has been secured, and the firm is planning for the introduction of the product to a market. Some organizations utilize contract employees or consultants during this stage in an effort to keep costs down while still being able to tap into research or administrative expertise.

In stage three, growth, how to obtain more market share and position the organization to serve more customers become the primary problems to be solved. The market has accepted the product as a success, leading to a period of steady growth. Much effort must be focused on keeping up with the growth through production and customer service functions.

Finally, in stage four, stability, the organization seeks more profitability through a focus on internal controls, while searching for a future growth base. The development of a second product offering is, in many cases, the solution to the growth issue. Adding professional managers is also desirable for stability firms, and they may support the founder or actually replace her. The addition of professional managers speeds the policy and procedure development so that the company becomes somewhat bureaucratized over time. While many organizational life cycle researchers add a fifth stage, decline, Kanzanjian (1988) chose not to, perhaps due to the model's focus on smaller enterprises.

Kazanjian's (1988) findings partially upheld the predictions, but some new insights were revealed. Support was found for propositions related to stages one, three, and partially to four. Predictions for stage two, however, found little support. Therefore, product or technology development and resource acquisition proved to be the dominant problems for firms in stage one. As for stage three, sales and marketing were rated as significantly more important than to firms in the other stages. In stage four firms, strategic positioning and organizational issues were rated as important problems. The study also yielded other findings of interest, including the importance of strategic positioning as an issue in all four stages by respondents. In addition, the people factor, attracting capable 
employees and talented managers, ranked second or third in each life cycle stage. And, the sales and marketing factor was rated first or second in three stages, emphasizing the importance of revenue growth to high technology firms.

Of primary importance to this discussion is the ranking of strategic positioning as a problem for firms in all four stages. Kazanjian defines strategic positioning as "a firm's position in a new product-market segment and the development of a new product or technology application." (1988: p. 269). Based on these earlier findings of Kazanjian (1988) and others previously discussed, we propose that SMEs acquire and develop information technology capabilities to aid in the solution of dominant problems for firms at each stage of the organizational life cycle as depicted in Figure 1. Four propositions are developed below.

Figure 1. Crisis and IT Capability Characteristics for the Kazanjian Life Cycle Model

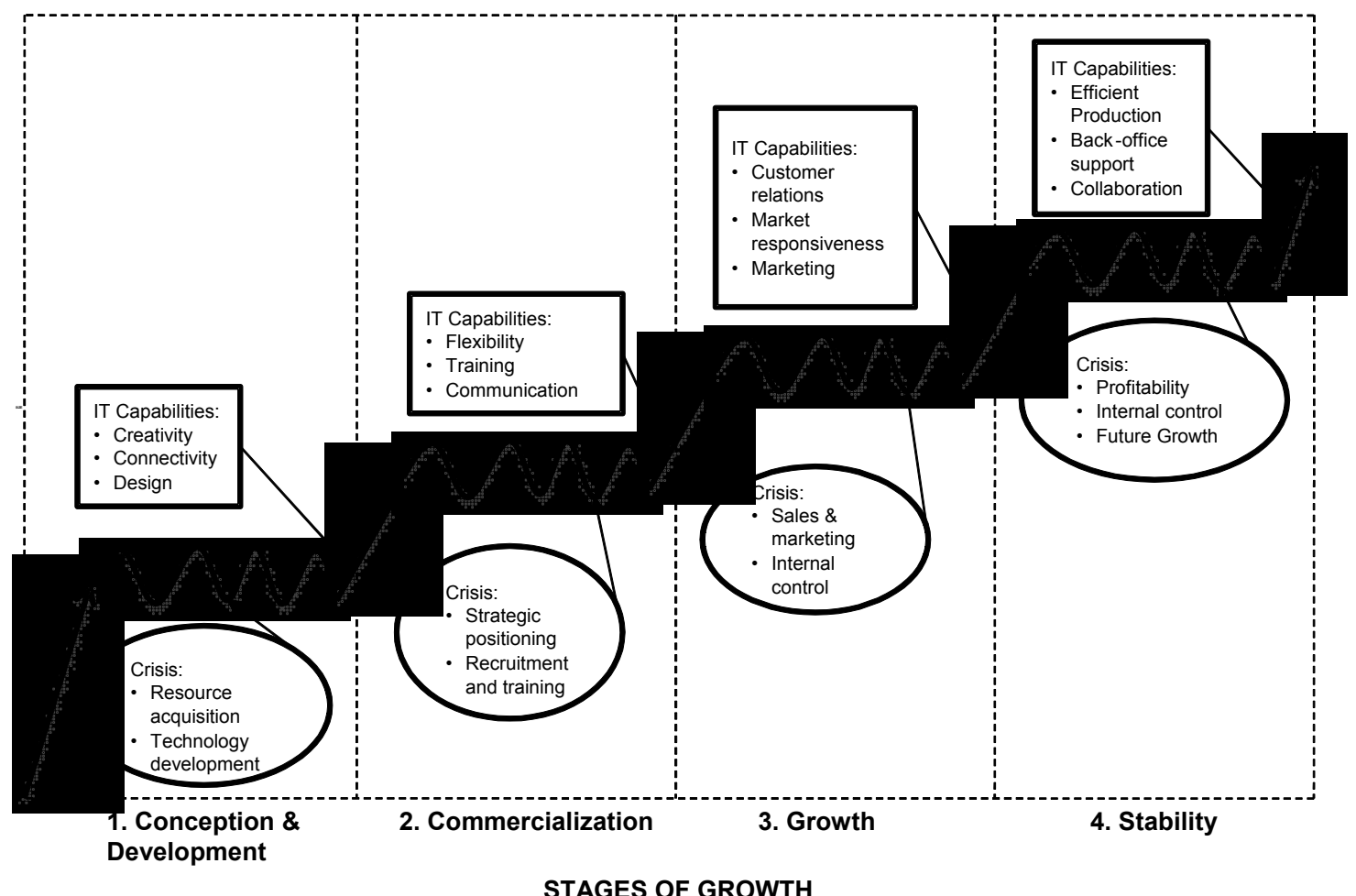

\section{Propositions}

In the conception and development stage, the firm is a newborn hungry for financial support, market recognition, and necessary resources. It needs to learn and develop its capabilities as quickly and as inexpensively as possible. A firm that can garner the most support from the market and financial community has a higher chance of surviving to the next stage. Numerous information technologies (IT) exist to connect the firm depending on the degree of openness with which the firm is comfortable. The most open and relatively inexpensive choice is to establish a web presence through a website that can be active or passive. At first, the site can be used for recruiting, information dissemination, 
and communication with potential suppliers, buyers, and industry experts. As the firm grows into the later stages, the website can be expanded to serve other functions discussed below. The danger with this openness is that the firm cannot always control who contributes comments to its website, and strong detractors may fatally harm this fledgling business. Open source collaboration is an alternative IT activity that enables the firm to develop projects with supplier and buyers while controlling access to the venture. For firms that need to protect their nascent product, the most closed IT activity is to use computer aided design/computer aided manufacturing (CAD/CAM) in which the entire design process is kept in-house.

There are costs and benefits from these IT capabilities For instance, CAD/CAM allows the firm to design and develop new products faster, but requires an investment in hardware and software in addition to training or hiring skilled workers to use the technology. In contrast, website management can be handled by one resident expert or outsourced while open source collaboration systems can be bought and maintained for a relatively lower cost because of the many vendors available. In the long run, the initial investment in these technologies will save the firm the future costs of infrastructure retrofits and employee retraining. Whichever the choice, the firm needs tools that can help it overcome its crisis of resource acquisition and technology development.

\section{Proposition 1: Firms in the conception and development stage will pursue IT capabilities that enable connectivity, creativity, and design activities.}

The crisis in stage 2 develops from the issues the firm faces as it commercializes its new product or service. Two critical issues identified in Kazanjian's study (1988) are the firm's strategic positioning and the task of getting the right managers and employees in place to embody and execute its vision. Strategic positioning is a tricky problem for a new product in an unknown and untested market. Although the firm may have an idea of to whom and how it should market its product, once in the market, the product will take on a life of its own, perhaps delving into unforeseen markets to serve unanticipated needs. While an IT capability cannot pick a market position for the firm's product, it can provide the necessary information and connections to assist the manager in making that decision, and it can enable the firm to be more responsive to evolving customer demands. Consequently, IT capabilities need to allow the firm to be flexible, agile, and knowledgeable about its customers while presenting and maintaining the company's core values consistently.

To enable the assessment and adaptation of new project developments, the firm could invest in project planning and scheduling software. An inventory management system would enable it to lower inventory costs and better plan production runs. The Internet could be used to link key value chain functions such as production, logistics, and marketing and sales enabling the sharing of 
key information to improve production efficiencies and meet customer expectations. As mentioned earlier, the company's website can be used as a recruiting tool, and it can be used also for routine training and communicating policy changes or improvements to targeted departments.

An underlying challenge in the commercialization stage is the more complex need for coordination among the various activities. As a result, IT capabilities will require a higher level of resource commitment in terms of finances, training, and time to implement and master. In deciding on an IT system, organizations need to consider long-term costs such as systems' compatibility, maintenance, and upgrade costs. Another danger in investing in an IT system is the possibility that the limitations of the IT system supersedes the needs of the organization, and new or innovative projects or ideas may be curtailed because they do not conform easily to the processes and procedures of the instituted technologies. If the firm can avoid this dilemma, the long-term benefits include enabling an internal culture of customer responsiveness, quality, and interdepartmental learning and collaboration.

Proposition 2: Firms in the commercialization stage will pursue IT capabilities that enable flexibility, training, and communication activities.

The third life cycle stage, growth, is marked by the need to increase market share through sales and marketing. Options for increasing sales include finding new market segments for its existing products, developing product tie-ins and add-ons for existing customers and products, modifying existing products for repeat customers, or entering international markets. An IT tool that is critical to this stage of a firm's life is customer relationship management (CRM) software (Campanelli, 2003). While young firms with few customers can usually manage them with day-to-day interactions, growing firms with hundreds or even thousands of customers require a system in place that, through a centralized data base, provides company employees in sales, marketing, customer service, and other functional areas access to up-to-date files on each customer.

The benefits of developing IT capabilities in an earlier stage can be reaped in the growth stage because the implemented technology infrastructure can enable sales and marketing efforts to develop new products and to reach new markets. The Internet is particularly useful for marketing and sales purposes because of its global reach and multimedia format. In addition, the growth stage firm can use emails and text messaging tools to send new product notifications and advertising to registered customers' email accounts, cell phones, and personal digital assistants (PDAs). At this stage, Internet functions can be expanded to include retailing, routine customer service as well as chatrooms and blogs to create a branded community which will encourage customer feedback, product identification, and interaction among community members. 
There are several weaknesses with using IT for marketing purposes. One major drawback to the use of IT in this stage is IT's limitations with products and services that require high levels of contact or interpersonal selling. In these markets, IT cannot replace the personal touch. Second, IT generates a vast amount of advertising noise which customers soon learn to ignore. Google and other search engines may yield hundreds of thousands of possible web links for an item search so firms that want to stand out in the crowd or make it to the top of the list will have to pay higher fees. A third difficulty is the lack of control over how the product is received and portrayed by the market; however, this difficulty may arise even without the use of IT. Despite these complications, the company's absence from the tech-sphere will not serve any purpose either. The success of viral marketing, using IT to tap into social networks for marketing, has shown that new technologies, like text messaging, cell phones, chatrooms, blogs, and social networking sites, play a vital role in providing personal endorsements for products. If the company can maintain a quality image and product, the benefits of IT outweigh its disadvantages in terms of marketing reach and advertising expenses.

Proposition 3: Firms in the growth stage will pursue IT capabilities that enable customer relations, market responsiveness, and marketing activities.

In the final stage of stability, the firm has reached a level of maturity in terms of sales revenues and now can focus on improving its operations to ensure profitability as it searches for the next source of revenues. Of particular concern is managing costs as competition increases among similar products and customers focus more on price. Although the activities in Stage 4 resemble those in previous stages, the SME can focus on making these activities more effective and efficient in the stability stage when production volumes are more consistent and predictable and the firm has sufficient slack resources to focus on these improvements. In addition, the search for new revenue streams in many ways involves the same capabilities discussed in Stage 1 Conception and Development.

Some of the IT capabilities introduced in the commercialization stage can assist with this task since they are designed to grow with the organization and improve its operational efficiencies. If the company has not already done so, automating routine office functions with accounting, purchasing, travel, and payroll software is a primary option for lowering costs. These systems can provide up to date information that can be utilized to improve operating efficiencies by lowering queuing, production or delivery time. Furthermore, the market, production, and personnel information collected by the software programs can be analyzed to help find additional operational efficiencies or new product and process innovations. For instance, information about personnel reward preferences may help to find non-monetary incentives to motivate its employees. Ultimately, an 
early investment in IT not only reduces costs and training time, but it can also provide a productivity or creativity boost in later stages.

The main problems with relying on technology are the possibility of a system failure and the occasional system shutdown for maintenance and upgrades. Although maintenance and upgrades can be scheduled during downtimes or slow times, organizations need to invest additional funds in back-up systems or have a protocol to deal with the event of a system failure.

Proposition 4: Firms in the stability stage will pursue IT capabilities that enable efficient production, back-office support, and collaboration activities.

Of course, the IT tools suggested in this research are not a complete listing of available options, but rather, a representative sample of options already available. Not only are new products being marketed every day, but creative entrepreneurs are finding new ways to use existing technologies. Once a firm understands the crisis it faces at each stage of its life cycle, it can develop the IT capabilities with the characteristics that best match its needs to better meet these challenges and facilitate its transition to the next stage of development.

\section{Implications for Managers}

Kazanjian's (1988) work produced three clear implications for practicing managers with regard to crises top managers face in each life cycle stage, and our follow-up discussion has proposed several IT capabilities that assist with solving those crises. While Kazanjian's (1988) findings are somewhat intuitive, they bear repeating because of their practical soundness. First, where a firm finds itself positioned in its primary market is important in all four stages of Kazanjian's (1988) life cycle. Second, making the most of attracting and retaining capable employees and talented managers is critical across all four life cycle stages. Finally, sales and marketing, never to be underestimated in any business, was rated first or second in importance in three of the four stages. Table 1 briefly summarizes our IT capability suggestions for solving the life cycle stage crises.

As Table 1 demonstrates, IT capabilities can help top managers address the crises that emerge at each life cycle stage. As an added benefit, over time the accumulation of additional IT implementations, if done properly, removes tedious distractions from managers' attention, providing more time for strategic growthoriented actions, rather than being bogged down with day-to-day operational inefficiencies. 
Table 1. Summary of IT Capability Suggestions for Kazanjian's Life Cycle Model

\begin{tabular}{|c|c|c|}
\hline Life Cycle Stage & Kazanjian's Problem Factors & IT Capability Suggestions \\
\hline $\begin{array}{l}\text { 1. Conception and } \\
\text { development }\end{array}$ & $\begin{array}{l}\text { - Product development } \\
\text { - Resource acquisition } \\
\text { - Sales/Marketing }\end{array}$ & $\begin{array}{l}\text { - Creativity -Open source collaboration; } \\
\text { Website } \\
\text { - Connectivity - Website; e-mail } \\
\text { - Design - CAD/CAM }\end{array}$ \\
\hline 2. Commercialization & $\begin{array}{l}\text { - Strategic positioning } \\
\text { - Recruitment and Training }\end{array}$ & $\begin{array}{l}\text { - Flexibility - Project planning and } \\
\text { scheduling software; Inventory } \\
\text { management system } \\
\text { - Training - Online recruitment and } \\
\text { training system } \\
\text { - Communication - Web-linked value } \\
\text { chain activities }\end{array}$ \\
\hline 3. Growth & $\begin{array}{l}\text { - Sales/Marketing } \\
\text { - Internal control }\end{array}$ & $\begin{array}{l}\text { - Customer relations - CRM software } \\
\text { - Market responsiveness - Blogs; e-mail; } \\
\text { Text messaging } \\
\text { - Marketing - Website; Social networking } \\
\text { site }\end{array}$ \\
\hline 4. Stability & $\begin{array}{l}\text { - Profitability } \\
\text { - Internal control } \\
\text { - Future growth }\end{array}$ & $\begin{array}{l}\text { - Efficient Production - Web-linked value } \\
\text { chain activities } \\
\text { - Back-office support - Automation } \\
\text { software for accounting, payroll, } \\
\text { purchasing, travel, etc. } \\
\text { - Collaboration - Website }\end{array}$ \\
\hline
\end{tabular}

Furthermore, the extant literature on IT capabilities in SMEs has focused mainly on the internal motivations and external pressures for IT investment, which is a static view of a dynamic process and assumes that all SMEs and information technologies are homogeneous. Our study recognizes that IT capabilities, like other capabilities, will evolve as the firm grows, and this evolution is closely tied to the crises that the organization faces at each life cycle stage. As a result, the firm will need different types of IT and/or the IT may serve a different function or need, depending on where the firm is in its development. In practice, the firm may adopt IT in incremental stages in keeping with its resource constraints.

\section{Conclusions and Future Directions}

We have examined ways in which a small business can improve its chances for survival and continued growth through the use of various information technology (IT) capabilities at each stage of the Kazanjian (1988) life cycle model to overcome the identified crises in each stage. In general, IT capabilities can increase the market reach of the nascent firm and improve its speed to market. IT tools can be relatively low cost to implement and maintain, and the technology itself does not have to be a barrier to implementation since many providers recognize that their customers are not tech savvy and offer service support. In later stages, IT capabilities can lower the firm's operating costs while improving 
market responsiveness. However, IT can never replace a skilled, experienced manager or make a sale in a high-contact sales environment.

A company that wants to develop IT capabilities will need to take into consideration the functions they serve, their ability to adapt and grow with the firm, long-term maintenance and upgrade costs as well as their user-friendliness. Because it is still just a tool, IT cannot help the firm if it has an inferior product that does not serve a market demand.

IT is, for most growing enterprises, just one factor contributing to continued progress and improved market share, but it has become if not sufficient, certainly necessary. The growth in number of IT adopters has grown dramatically in recent years with many firms already looking to upgrade to the newest IT models (Riemenschneider \& Mykytyn, 2000). Reported survey results show that $58 \%$ of small businesses in the study stated that IT played an important role in their success, and $61 \%$ felt that it had a positive effect on their net income (Greenspan, 2002). However, IT investments that are used only as a tool is not sufficient; instead, it must be viewed as a capability to be integrated with other core capabilities and used strategically (Kim \& Jee, 2007).

While SMEs struggle with stretching resources to meet ever-increasing demands as they grow, IT investment may prove to be unavoidable.

Future research efforts should delve into the differences in IT investment and development between growing organizations versus those that are stagnant or even out of business. Of particular relevance will be the relationship between the IT investment and how it fits with the overall strategic direction of the organization.

\section{References}

Adizes, I. (1979). Organizational passages: Diagnosing and treating life cycle problems in organizations. Organizational Dynamics, 8, 3-24.

Aguila-Obra, A.R. \& Padilla-Melendez, A. (2006). Organizational factors affecting internet technology adoption. Internet Research, 16 (1), 94-110.

Bruque, S. \& Moyano, J. (2007). Organisational determinants of information technology adoption and implementation in SMEs: The case of family and cooperative firms. Technovation, 27, 241-253.

Campanelli, M. (July, 2003). Relationship Issues. Entrepreneur, 42-43.

Child, (1972). Organization structure, environment, and performance: The role of strategic choice. Sociology, 6, 2-22.

Churchill, N., \& Lewis, V. (May-June, 1983). The five stages of small business growth. Harvard Business Review, 61, 30-50. 
Clarysse, B. \& Bruneel, J. (2007). Nurturing and growing innovative start-ups: The role of policy as integrator. R\&D Management, 37, 139-149.

Dedrick, J., Gurbaxani, V., \& Kraemer, K. (2003). Information technology and economic performance: A critical review of the empirical evidence. ACM Computing Surveys, 35 (1), 1-28.

Dodge, H., Fullerton, S., \& Robbins, J. (1994). Stage of the organizational life cycle and competition as mediators of problem perception for small businesses. Strategic Management Journal, 15, 1221-134.

Drazin, R., \& Kazanjian, K. (1990). Research notes and communications: A reanalysis of Miller and Friesen's life cycle data. Strategic Management Journal, 11, 319-325.

Galbraith, J. (1982). The stages of growth. Journal of Business Strategy, 3 (4), 70-79.

Grandon, E.E. \& Pearson, J.M. (2004). Electronic commerce adoption: an empirical study of small and medium us businesses. Information \& Management, 42, 197-216.

Greenspan, R. (March 28, 2002). Small Biz Benefits from Internet Tools. Clickz.com. Retrieved at www.clickz.com.

Greiner, L. (1972). Evolution and revolution as organizations grow. Harvard Business Review, 50 (4), 37-46.

Hanks, S. (1990). An empirical examination of the organizational life cycle in high technology firms. Doctoral dissertation, University of Utah.

Hanks, S., Watson, C., Jansen, E., \& Chandler, G. (1994). Tightening the life cycle construct: a taxonomic study of growth stage configurations in hightechnology organizations. Entrepreneurship Theory \& Practice, 2, 5-29.

Ireland, D.C. \& Hine, D. (2007). Harmonizing science and business agendas for growth in new biotechnology firms: Case comparisons from five countries. Technovation, 27, 676-692.

Jawahar, I.M. \& McLaughlin, G.L. (2001). toward a descriptive stakeholder theory: an organizational life cycle approach. Academy of Management Review, 26, 397-414. 
Kazanjian, R. (1988). Relation of dominant problems to stages of growth in technology-based new ventures. Academy of Management Journal, 31, 257279.

Kim, M-K, \& Jee, K-Y. (2007). Factors influencing strategic use of information technology and its impact on business performance of SMEs. ETRI Journal, 29, 497-506.

Kimberly, J., \& Miles, R. (1980). The organizational life cycle. San Francisco: Jossey-Bass Publishers.

Lamburg, J-A., \& Pajunen, K. (2005). Beyond the metaphor: The morphology of organizational decline and turnaround. Human Relations, 58, 947-980.

Lester, D., \& Parnell, J. (2006). The complete life cycle of a family business. Journal of Applied Management and Entrepreneurship, 11 (3), 3-22.

Lester, D., Parnell, J., \& Carraher, S. (2003). Organizational life cycle: A fivestage empirical scale. International Journal of Organizational Analysis, 11, 339-354.

Lohdal, T., \& Mitchell, S. (1980). Drift in the development of innovative organizations. In, Kimberly, J., \& Miles, R. (Eds.), The organizational life cycle (pp. 184-207). San Francisco: Jossey-Bass Publishers.

Lynall, M.D., Golden, B.R., \& Hillman, A.J. (2003). Board composition from adolescence to maturity: A multitheoretic view. Academy of Management Review, 28, 416-431.

Masurel, E. \& van Montfort, K. (2006). Life cycle characteristics of small professional service firms. Journal of Small Business Management, 44, 461473.

Maurer, I. \& Ebers, M. (2006). Dynamics of social capital and their performance implications: lessons from biotechnology start-ups. Administrative Science Quarterly, 51, 262-292.

McMahon, R.G.P. (2001). Deriving an empirical development taxonomy for manufacturing SMEs using data from Australia's Business Longitudinal Survey. Small Business Economics, 17, 197-212.

Mehrtens, J., Cragg, P.B., \& Mills, A.M. (2001). A model of internet adoption by SMEs. Information \& Management, 38, 165-176.

Miller, D., \& Friesen, P. (1984). A longitudinal study of the corporate life cycle. Management Science, 30, 1161-1183. 
Morse, E.A., Fowler, S.W., \& Lawrence, T.B. (March, 2007). The impact of virtual embeddedness on new venture survival: Overcoming the liabilities of newness. Entrepreneurship Theory \& Practice, 139-159.

Oviatt, B. \& McDougall, P. (1995). Global start-ups: entrepreneurs on a worldwide stage. Academy of Management Executive, 92, 30-43.

Pool, P., Parnell, J., Spillan, J., Carraher, S., \& Lester, D. (2006). Are SMEs meeting the challenge of integrating e-commerce into their businesses? A review of the development, challenges and opportunities. International Journal of Information Technology and Management. 5 (2/3), 97-113.

Premkumar, G. (2003). A meta-analysis of research on information technology implementation in small business. Journal of Organizational Computing and Electronic Commerce, 13, 91-121.

Quinn, R., \& Cameron, K. (1983). Organizational life cycles and shifting criteria of effectiveness: Some preliminary evidence. Management Science, 29, 33-41.

Rao, S., Metts, G., \& Monge, C. (2003). Electronic commerce development in small and medium size enterprises. Business Process Management Journal, 9 (11), 11-32.

Rasheed, H.S. (2005). Turnaround strategies for declining small business. Journal of Developmental Entrepreneurship, 10, 239-252.

Riemenschneider, C.K. \& Mykytyn, P.P. Jr. (2000). What small business executives have learned about managing information technology. Information \& Management, 37, 257-269.

Rutherford, M.W., Buller, P.F., \& McMullen, P.R. (2003). Human resource management problems over the life cycle of small to medium-sized firms. Human Resource Management, 42, 321-335.

Smith, K., Mitchell, T., \& Summer, C. (1985). Top level management priorities in different stages of the organizational life cycle. Academy of Management Journal, 28, 799-820.

Starbuck, (1971). Organizational growth and development. London: Penguin Books.

Stimmel, A. (2001). The nuts and bolts of moving into e-commerce. Consulting to Management, 12 (4), 46-50. 
Vohora, A., Wright, M., \& Lockett, A. (2004). Critical junctures in the development of university high-tech spinout companies. Research Policy, 33 (1), 147-175. 